\title{
Bovine cysticercosis and human taeniasis: Animal-human health and economic approach with treatment trends in Kombolcha Town, Wollo, Ethiopia
}

\author{
Aragaw Tegegne ${ }^{1}$, Adem Hiko ${ }^{1}$ and Kemal Kedir Elemo ${ }^{2}$
}

1. Department of Veterinary Public Health, College of Veterinary Medicine, Haramaya University, Po. Box. 138 Dire Dawa, Ethiopia; 2. Department of Animal Sciences, School of Agriculture and Natural Resources, Animal and Range Sciences, Madda Walabu University, Po. Box. 274 Bale-Robe, Ethiopia.

Corresponding author: Adem Hiko, e-mail: adex.2010ph@gmail.com

Co-authors: AT: aragaw792@gmail.com, KKE: kkedir8@gmail.com

Received: 26-12-2017, Accepted: 26-01-2018, Published online: 07-03-2018

doi: 10.14202/IJOH.2018.15-21 How to cite this article: Tegegne A, Hiko A, Elemo KK. Bovine cysticercosis and human taeniasis: Animal-human health and economic approach with treatment trends in Kombolcha Town, Wollo, Ethiopia. Int J One Health 2018;4:15-21.

\begin{abstract}
Background and Aim: Bovine cysticercosis and human taeniasis accounted for parasitic zoonotic implications with economic losses from organ contamination and treatment cost. The disease is common where hygienic conditions are poor and the inhabitants traditionally eat raw or insufficiently cooked meat under inadequate community awareness on the associated risk factors for the occurrences of infections in developing countries such as Ethiopia. The aim of this study was to assess bovine cysticercosis and Taenia saginata human taeniasis considering animal-human health and economic approach with treatment trends in Kombolcha Town, Wollo, Ethiopia.
\end{abstract}

Materials and Methods: A cross-sectional study was conducted in cattle slaughtered at Kombolcha ELFORA abattoir from November 2016 to April 2017. A questionnaire survey was applied for community awareness, exposure risk, and treatment trends for taeniasis assessment in Kombolcha Town with economic losses from organ condemnation, and drug cost for taeniasis treatments were estimated.

Results: Of the 234 examined carcasses, 21 (8.97\%) were found infected with bovine cysticercosis. Organ distribution of the cysts showed highest proportions in liver 40 (29.2\%), followed by heart $26(18.9 \%)$, tongue $22(16.1 \%)$, masseter muscle 20 (14.6\%), triceps 15 (10.9\%), diaphragm 9 (6.7\%), and lung 5 (3.6\%). Both male, i.e., 15 (6.4\%), and female, i.e., 6 (12.8\%), were infected. Regardless of sample size, Cysticercus bovis infection was found 8 (21.62\%) in adults and $13(6.60 \%)$ older aged. Of 110 interviewed individuals, about 31.8\% aware of taeniasis and they also have exposure risk for taeniasis with no differences $(\mathrm{p}>0.05)$ within studied demography. The majorities $(54.3 \%)$ of exposed groups use pharmaceutical drugs, while $28.6 \%$ use herbal medicine, but $17.2 \%$ use both for treatment. Of 31,469 clinical cases in Kombolcha Town, $22(0.07 \%)$ were positive for taeniasis over the year 2016. An inventory of pharmaceutical shops revealed the supply of 6998 adult taenicidal drug doses for a cost of 19,621.00 Ethiopian Birr (ETB) where mebendazole and albendazole were the most frequent. A total annual economic loss of 1,841,311.00 ETB (73,652.44 USD) consisting of 1,831,890.00 ETB from organ condemnation and 19,421.00 ETB from taenicidal drug cost was estimated.

Conclusion: The present finding indicates the need for community awareness creation regarding the disease condition, associated risk factors, and application of environmental hygiene which could bring a paramount reduction of diseases in human and beef industry which prevent the associated economic loss.

Keywords: abattoir, Cysticercus bovis, economic loss, Ethiopia, Kombolcha, taeniasis.

\section{Introduction}

Cysticercosis, caused by Taenia saginata, is among the diseases affecting food safety [1]. The bovine cysticercosis is a the metacestode stage in cattle where the adult is parasitic zoonosis in human intestinal, $T$. saginata [2]. In developed countries, low prevalence of cysticercosis $(<1 \%)$ in carcasses [3] but high and very common occurrences in African countries reaching

\footnotetext{
Copyright: Tegegne, et al. This article is an open access article distributed under the terms of the Creative Commons Attribution 4.0 International License (http://creativecommons.org/licenses/ by/4.0/), which permits unrestricted use, distribution, and reproduction in any medium, provided you give appropriate credit to the original author(s) and the source, provide a link to the Creative Commons license, and indicate if changes were made. The Creative Commons Public Domain Dedication waiver (http:// creativecommons.org/ publicdomain/zero/1.0/) applies to the data made available in this article, unless otherwise stated.
}

a level of $30-36 \%$ in Kenya, 20\% in Guinea, $18 \%$ in Sierra Leone, and 20\% in Cameroon [4] were reported. Florova [5] reported a prevalence of $100 \%$ which is the highest in Africa and also in the world. The World Health Organization [6] included cysticercosis as a part of the neglected zoonoses subgroup in tropical diseases. In Ethiopia, the prevalence of Cysticercus bovis has been reported with 3.65\% [7] and 26.3\% [8] based on abattoir survey while $T$. saginata with $64.44 \%$ [7] and $64.2 \%$ [8] based on questionnaire survey. As a result, human health, the esthetic value of meat, and trading of meat and offal are compromised [9]. In some parts of Ethiopia, habit of raw or undercooked beef consumption is the source of T. saginata infection in human [10]. Tembo [11] reported the prevalence of $89.41 \%$ in different agroclimate zones associating this high prevalence 
with the habit or culture of raw or undercooked beef consumption in Ethiopia.

Besides, considerable amount of economic losses approaching 30\% due to bovine cysticercosis from carcass weight loss and the cost of freezing for the infected meat [12], investigation, grade of the infected animals from markets, and treatment costs for detained carcass [13] accounted huge in Africa. Moreover, medical costs for taeniasis treatment of infected human $[14,15]$ and cost of taenicidal drugs are also reported. In Ethiopia, treatment cost of 4,937,583.21 ETB $(225,036.97$ USD) has been estimated [16].

Bovine cysticercosis is widely distributed in Ethiopia with a prevalence of $9.7 \%$ in Bishoftu [17], $21 \%$ in Nekemte [18], 6.4\% in Kombolcha [19], 4.9\% in Assele [20], and 3.2\% in Ethiopian different agroclimatic zones [11]. However, community awareness, exposure risk, and treatment trends for taeniasis in Kombolcha Town were not yet assessed. This study was aimed to assess animal-human health and economic loss aspects with treatment trends of bovine cysticercosis and taeniasis in Kombolcha Town, Wollo, Ethiopia.

\section{Materials and Methods}

\section{Ethical approval}

Examination of animal and interview of human beings were made in this study. Thus, ethical clearance was obtained from College of Veterinary Medicine, Haramaya University Ethical Committee. Informed consent was obtained from the participants.

\section{Study area}

The study was conducted from November 2016 to April 2017 at Kombolcha Town, northeast part of Ethiopia at a distance of about $377 \mathrm{~km}$ from the capital city (Addis Ababa), located at $11^{\circ} 08^{\prime} \mathrm{N}$ and $39^{\circ}$ $74^{\prime} \mathrm{E}$, and has an elevation of $1883 \mathrm{~m}$ above the sea level. The area receives $1500-1840 \mathrm{~mm}$ rainfall annually with the minimum and maximum temperature of $11.7^{\circ} \mathrm{C}$ and $23.9^{\circ} \mathrm{C}$, respectively [21].

\section{Study population}

The study population was local zebu cattle (Bos indicus) from Dessie Zuria, Kemissie, Kombolcha, South Tigray, West Afar, and South Gondar woredas and slaughtered at Kombolcha ELFORA abattoir. The average minimum and maximum numbers of animals slaughtered per day were 50 and 70 , respectively. The study population also consists of randomly selected human inhabitant population in Kombolcha Town interviewed for the questionnaire survey.

\section{Study design}

A cross-sectional study was conducted to determine the prevalence and economic hurt associated with bovine cysticercosis in cattle slaughtered at Kombolcha ELFORA abattoir. Similarly, a questionnaire survey was applied to randomly selected individuals to assess community awareness, exposure risk, and treatment trends for taeniasis in Kombolcha Town. One-year retrospective drug shop inventory was also applied to estimate the economic losses due to taeniasis treatments in human cases.

\section{Sample size determination}

The desired sample size was calculated using the formula recommended by Thrusfield [22] with 95\% confidence level, 6.4\% expected prevalence [19], desired absolute precision, and expected prevalence. Therefore, the required sample size for animals was calculated as follows:

$$
\mathrm{N}=\frac{1.96^{2} \times \mathrm{P} \exp (1-\mathrm{P} \exp )}{\mathrm{d}^{2}}
$$

where $\mathrm{N}=$ required sample size, Pexp = expected prevalence, $\mathrm{d}=$ desired absolute precision (usually 0.05 ), and $1.96=\mathrm{Z}$-value for $95 \%$ confidence level.

Accordingly, the sample size becomes 93 animals which was increased up to 234 animals.

For questionnaire survey, the sample size was calculated using the formula given by Arsham [23] which is as follows:

$\mathrm{N}=0.25 / \mathrm{SE}^{2}$,

$$
\begin{aligned}
\text { where } \mathrm{N}= & \text { sample size and SE (standard error) } \\
& =5 \% .
\end{aligned}
$$

Thus, the sample size required for the questionnaire survey was 100 , but 110 volunteers were included with proportion distribution according to demographic and other study factors.

\section{Study methodology}

\section{Abattoir survey}

Abattoir survey was conducted using detailed meat inspection on randomly selected cattle antemortem inspection according to the FAO [24] and slaughtered at Kombolcha ELFORA abattoir. Factors such as animal origin, breed, age, sex, and body condition scores were recorded before slaughtering. Postmortem examination was conducted by visualization, inspection, palpation, and systematic incision of each of visceral organs such as liver, lung, heart, and tongue and muscles such as masseters, diaphragm, and triceps for the presence of parasites and other abnormalities [25]. The presence or absence as well as the anatomical distribution of the cysts count by organ or muscle was registered.

\section{Community awareness, exposure risk, and treatment trends for taeniasis}

Community awareness on the use of latrine availability, meat consumption habit, meat source, knowledge of taeniasis, source of information on the diseases, use of drug for treatment, aware of the route of transmission, and knowledge on prevention mechanism was incorporated in the questionnaire. Exposure risk to taeniasis was assessed using demographics 
such as gender, age categories, occupation, educational status, residence location, and marital status of the respondent. Taeniasis treatment trends of community were assessed whether an individual used pharmaceutical drug, herbal medicine, or both.

\section{Retrospective assessment of 1-year data}

Retrospective clinical cases reported of human taeniasis was assessed. Records from two selected private clinics and three public health centers found in Kombolcha Town were assessed. Similarly, for the year 2016, taeniacidal drugs frequently supplied by the local pharmacy in the area were assessed in four private pharmacies and three health center drug stores.

\section{Estimation of economic loss}

The total financial loss due to organ condemnation was computed based on the condemnation rate of each type of examined organs, average number of animals slaughtered in the abattoir per year from retrospective data, and condemnation rate of each organ. Accordingly, the total direct financial loss was calculated by the formula given by Oguninade and Ogunrinade [26] as $\mathrm{DAL}=\sum \mathrm{AC} \times \mathrm{AP} \times \mathrm{CR}$ (where $\mathrm{DAL}=$ direct annual financial loss due to organs condemnation, $\mathrm{AC}=$ annual cattle slaughter rate of the abattoir, AP = average cost of each liver/lung/heart/ tongue, and $\mathrm{CR}=$ condemnation rates of liver/lung/ heart/tongue).

The taeniacidal drugs supplied during the year 2016 inventory was conducted at drug shops. The cost was estimated using yearly adult taenicidal drug doses. The cost incharge of pharmacies from the records (prescription papers and patient complaints) was collected. The total cost of taenicidal drug doses was calculated and estimated at annual cost.

\section{Data management and analysis}

The abattoir survey, questionnaire, clinical case reports, and drug shop inventory data were recorded and entered into Microsoft Excel $2013^{\circ}$ and analyzed using STATA software version 11.0 (Stata Corp, 2009). From the abattoir data, percentage and Chi-square $\left(\chi^{2}\right)$ were calculated. Anatomical distribution of metacestodes (C. bovis) was tabulated and described by proportional distribution of the cyst. Questionnaire data were categorized into demographic and other study factors for the occurrence of taeniasis among different respondents groups. Inventory data of pharmaceutical shops were described using frequency. Economic losses from animal organ contamination and human treatment drugs were calculated both in Ethiopian Birr (ETB) and USD. A level of significance of $p<0.05$ was used to assess the differences.

\section{Results}

Prevalence and organ distribution of bovine cysticercosis

As shown in Table-1, an overall prevalence of bovine cysticercosis was $21(8.97 \%)$, indicating no significant difference among animal origin as well as between animal sex groups ( $p>0.05$ ). Regardless of number of animal examined, Cysticercus bovis was $21.6 \%$ in adult and $6.6 \%$ in old age animals.

A total of 137 cysts were detected from 21 cysticercosis-positive animals during the study period. Using organ and tissue distribution, the prevalence of C. bovis was ranged from $5.6 \%$ in the liver to $0.9 \%$ in the lung in positive animals (Table-2). The proportion counted cyst was higher in the liver $(29.2 \%)$, heart $(19.10 \%)$, tongue $(16.0 \%)$, masseter muscles (14.6\%), triceps muscle (11.0\%), and the lungs (3.6\%) in descending order.

\section{Economic losses associated with bovine cysticercosis}

Direct annual financial loss of the abattoir from slaughtered cattle in 2016 accounted 5257.00 ETB with the corresponding average cost of organs (liver - $45 \mathrm{ETB}$, heart - $30 \mathrm{ETB}$, lung - $20 \mathrm{ETB}$, and tongue - 55 ETB), based on information given by the abattoir's health control and marketing director.

Table-1: Prevalence of Cysticercus bovis by the studied risk factors.

\begin{tabular}{lcccc}
\hline Risk factors & $\begin{array}{c}\text { Number of } \\
\text { examined }\end{array}$ & $\begin{array}{c}\text { Number of } \\
\text { positive (\%) }\end{array}$ & $\chi^{\mathbf{2}}$ & p value \\
\hline $\begin{array}{l}\text { Origin } \\
\text { Dessie Zuria }\end{array}$ & 28 & $3(10.71)$ & 1.96 & 0.854 \\
$\begin{array}{l}\text { Kombolcha } \\
\text { Kemissie }\end{array}$ & 43 & $4(9.30)$ & & \\
$\quad$ South & 39 & $1(2.86)$ & & \\
$\quad$ Tigray & & $4(10.26)$ & & \\
$\quad$ South & 32 & $3(9.38)$ & & \\
$\quad$ Gondar & & & & \\
$\quad$ West afar & 57 & $6(10.53)$ & & \\
Sex & & & & \\
Female & 47 & $6(12.77)$ & 1.04 & 0.309 \\
$\quad$ Male & 187 & $15(8.02)$ & & \\
Age & & & & \\
Adult & 37 & $8(21.62)$ & 8.61 & 0.003 \\
$\quad$ Old & 197 & $13(6.60)$ & & \\
BCS & & & & \\
Poor & 218 & $15(6.88)$ & $*$ & $*$ \\
Medium & 14 & $6(42.86)$ & & \\
$\quad$ Good & 2 & $0(0.00)$ & & \\
Total & 234 & $21(8.97)$ & & \\
\hline
\end{tabular}

*Not calculated due to zero cell

Table 2: Organ distribution of Cysticercus bovis among positive animals.

\begin{tabular}{lccc}
\hline \multicolumn{2}{l}{ Tissues and organ prevalence } & & $\begin{array}{c}\text { Cyst count and } \\
\text { proportion }\end{array}$ \\
${$\cline { 1 - 1 }$}$ inspected $(\mathbf{N = 2 3 4 )} }$ & $\begin{array}{c}\text { Number (\%) } \\
\text { of positive }\end{array}$ & & $\begin{array}{c}\text { Number (\%) } \\
\text { proportion of } \\
\text { cysts }(\mathbf{N}=137)\end{array}$ \\
\hline Liver & $13(5.6)$ & & $40(29.2)$ \\
Heart & $11(4.7)$ & & $26(19.0)$ \\
Masseters & $11(4.7)$ & & $20(14.6)$ \\
Triceps & $10(4.2)$ & & $15(11.0)$ \\
Tongue & $9(3.8)$ & & $22(16.0)$ \\
Diaphragm & $5(2.1)$ & & $9(6.6)$ \\
Lung & $2(0.9)$ & $5(3.6)$ \\
\hline
\end{tabular}


Table 3: Community awareness/knowledge about association of studied factors with risk of Taenia saginata contraction.

\begin{tabular}{|c|c|c|c|c|}
\hline Studied factors & Number of interviewed & $\begin{array}{l}\text { Presence of awareness on taeniasis } \\
\qquad N(\%)\end{array}$ & $\chi^{2}$ & p value \\
\hline \multicolumn{5}{|l|}{ Latrine availability } \\
\hline Present & 98 & $33(33.67)$ & 1.43 & 0.233 \\
\hline Absent & 12 & $2(16.67)$ & & \\
\hline \multicolumn{5}{|l|}{ Meat consumption habit } \\
\hline Raw meat & 19 & $6(31.58)$ & 1.16 & 0.762 \\
\hline Partially cooked & 5 & $1(20.00)$ & & \\
\hline Raw and partially cooked & 14 & $6(42.86)$ & & \\
\hline Well cooked & 72 & $22(30.56)$ & & \\
\hline \multicolumn{5}{|l|}{ Meat source } \\
\hline Local butcher & 77 & $25(32.47)$ & 0.33 & 0.848 \\
\hline Abattoir & 11 & $4(36.36)$ & & \\
\hline Own slaughter & 22 & $6(27.27)$ & & \\
\hline \multicolumn{5}{|l|}{ Heard of taeniasis } \\
\hline Yes & 72 & $35(48.61)$ & * & * \\
\hline No & 38 & $0(0.00)$ & & \\
\hline \multicolumn{5}{|l|}{ Source of information } \\
\hline Social media & 13 & $8(61.54)$ & 2.7639 & 0.429 \\
\hline Health center & 15 & $5(33.33)$ & & \\
\hline Veterinarian & 12 & $7(58.33)$ & & \\
\hline Social interaction & 32 & $15(46.88)$ & & \\
\hline \multicolumn{5}{|l|}{ Drug use } \\
\hline Yes & 35 & $35(100)$ & $*$ & $*$ \\
\hline No & 75 & $0(0)$ & & \\
\hline \multicolumn{5}{|l|}{ Rout of transmission } \\
\hline Contact & 13 & $10(76.92)$ & * & * \\
\hline Raw meat & 59 & $25(42.37)$ & & \\
\hline I don't know & 38 & $0(0.0)$ & & \\
\hline \multicolumn{5}{|l|}{ Knowledge about prevention } \\
\hline Hygiene keeping & 18 & $6(33.33)$ & * & * \\
\hline Cooked meat & 31 & $14(45.16)$ & & \\
\hline Meat from abattoirs & 11 & $5(45.45)$ & & \\
\hline All & 11 & $10(90.91)$ & & \\
\hline Not know & 39 & $0(0.00)$ & & \\
\hline Total & 110 & $35(31.82)$ & & \\
\hline
\end{tabular}

*Not calculated due to zero cell

Annual organ rejection rate for inspected organs costs $1,831,890.00$ ETB which is equivalent to $76,328.75$ USD in Kombolcha abattoir.

\section{Human taeniasis}

Of the total 110 voluntary respondents interviewed, $31.8 \%$ of them was knowledgeable on considered risk factors for infections with taeniasis ( $T$. saginata). Out of 110 volunteers interviewed, $76.9 \%$ and $42.4 \%$ of respondents were aware that the source of infection is raw or undercooked meat, respectively (Table-3).

The respondents were confirmed with human taeniasis ( $T$. saginata), witnessing that they observed proglottids in their feces. Accordingly, the prevalence was $36.6 \%$ in male but $23.1 \%$ in female. Similar and about $32 \%$ prevalence was found in both the rural and urban areas inhabitant individuals (Table-4).

\section{Frequently used drugs and treatment trends of human taeniasis}

Of taeniasis patients, gastrointestinal syndromes characterized by nausea $(40.0 \%)$ and abdominal pain $(37.1 \%)$ were frequent. Most of the exposed individuals to taeniasis $(54.3 \%)$ used modern pharmacy, while $28.6 \%$ used herbal medicine, and the remaining $17.2 \%$ used both (Table-5).

Of 31,469 clinical cases, human taeniasis accounted, $22(0.07 \%)$. It was $0.1 \%$ in males but $0.04 \%$ in female (Table- 6 ).

A total of 6998 taeniacidal drug dose with highest for mebendazole (4942) and albendazole (1625) were supplied by pharmacies in the studied area (Table-7). A total cost for 1-year taeniacidal drugs accounted for $19,421.00$ ETB in the area.

\section{Discussion}

Bovine cysticercosis is reported in various countries including Ethiopia, as a major parasite disease contributing to low meat productivity, role in organ condemnation, and public health risk [3-5,27,28]. The present $8.97 \%$ bovine cysticercosis indicated the risk in Kombolcha and the surrounding, which is comparable with $8.6 \%$ in Halaba municipal abattoir [29], 7.5\% in Addis Ababa abattoir [30], 11.3\% in Wolita Sodo [28], 6.7\% in Kombolcha [31], and 6.4\% in Kombolcha [19]. However, the present finding 
Table-4: Community exposure risk to taeniasis in respective of the demography of participants in Kombolcha Town, Wollo, Ethiopia.

\begin{tabular}{|c|c|c|c|c|}
\hline $\begin{array}{l}\text { Demography of } \\
\text { studied participants }\end{array}$ & Number of interviewed & $\begin{array}{l}\text { Exposure risk to taeniasis } \\
N(\%)\end{array}$ & $\chi^{2}$ & p value \\
\hline \multicolumn{5}{|l|}{ Gender } \\
\hline Female & 39 & $9(23.08)$ & 2.12 & 0.145 \\
\hline Male & 71 & $26(36.62)$ & & \\
\hline \multicolumn{5}{|l|}{ Age (years) } \\
\hline $15-24$ & 12 & $2(16.67)$ & 2.17 & 0.538 \\
\hline $25-34$ & 47 & $14(29.79)$ & & \\
\hline $35-45$ & 31 & $11(35.48)$ & & \\
\hline$>45$ & 20 & $8(40.00)$ & & \\
\hline \multicolumn{5}{|l|}{ Occupation } \\
\hline Gov. employee & 16 & $4(25.00)$ & 2.29 & 0.681 \\
\hline Private employee & 41 & $12(29.27)$ & & \\
\hline Student & 30 & $9(30.000$ & & \\
\hline Farmer & 10 & $4(50.00)$ & & \\
\hline Merchant & 13 & $5(38.46)$ & & \\
\hline \multicolumn{5}{|l|}{ Educational status } \\
\hline Primary school & 24 & $7(29.17)$ & 1.4 & 0.712 \\
\hline College and above & 45 & $13(28.89)$ & & \\
\hline Secondary and prep & 24 & $10(41.67)$ & & \\
\hline Illiterate & 17 & $5(29.41)$ & & \\
\hline \multicolumn{5}{|l|}{ Resident } \\
\hline Rural & 18 & $6(33.33)$ & 0.02 & 0.880 \\
\hline Urban & 92 & $29(31.52)$ & & \\
\hline \multicolumn{5}{|l|}{ Marital status } \\
\hline Married & 65 & $25(38.46)$ & 3.23 & 0.072 \\
\hline Single & 45 & $10(22.22)$ & & \\
\hline \multicolumn{5}{|l|}{ Meat consumption habit } \\
\hline Cooked meat & 31 & $14(45.16)$ & $*$ & \\
\hline $\begin{array}{l}\text { Raw meat from } \\
\text { abattoirs }\end{array}$ & 11 & $5(45.45)$ & & \\
\hline All & 11 & $10(90.91)$ & & \\
\hline Not know & 39 & $0(0.00)$ & & \\
\hline Total & 110 & $35(31.82)$ & & \\
\hline
\end{tabular}

*Not calculated due to zero cell

Table-5: Symptom encountered for exposed respondent and treatment trends in Kombolcha Town, Wollo, Ethiopia.

\begin{tabular}{|c|c|c|c|c|}
\hline \multirow[t]{2}{*}{ Community skill on symptom } & \multirow[t]{2}{*}{ Number $(\%)$ of exposed respondent $(\mathrm{N}=35)$} & \multicolumn{3}{|c|}{$\begin{array}{c}\text { Treatment drug source } \\
\text { N }(\%)\end{array}$} \\
\hline & & Pharmacy & Herbal & Both \\
\hline Nausea & $14(40.0)$ & $8(57.1)$ & $3(21.4)$ & $3(21.4)$ \\
\hline Abdominal pain & $13(37.1)$ & $9(69.2)$ & $3(23.1)$ & $1(7.7)$ \\
\hline Diarrhea & $2(5.7)$ & 0 & $1(50.0)$ & $1(50.0)$ \\
\hline Head ache & $1(2.9)$ & $1(100)$ & 0 & 0 \\
\hline All signs listed & $5(14.3)$ & $1(20.0)$ & $3(60.0)$ & $1(20.0)$ \\
\hline Total & $35(100)$ & $19(54.3)$ & $10(28.6)$ & $6(17.2)$ \\
\hline
\end{tabular}

Table-6: Retrospective clinical case reported human taeniasis in studied area.

\begin{tabular}{lccc}
\hline Sex & $\begin{array}{c}\text { Number of } \\
\text { examined }\end{array}$ & $\begin{array}{c}\text { Number of } \\
\text { positive cases }\end{array}$ & Prevalence (\%) \\
\hline Male & 15,048 & 15 & 0.10 \\
Female & 16,421 & 7 & 0.04 \\
Total & 31,469 & 22 & 0.07 \\
\hline
\end{tabular}

was lower than the findings $21 \%$ at Nekemt [18], $26.25 \%$ at Hawassa abattoir [8], 18.49\% in North west Ethiopia [32], and $17.5 \%$ in East Shoa [33] all from Ethiopia. The differences could be due to variation geographic area associated with statues of personal hygiene, frequencies of raw meat consumption, and
Table-7: Taeniacidal drugs frequently supplied in the area and the annual cost over the year 2016.

\begin{tabular}{lcc}
\hline $\begin{array}{l}\text { Name of } \\
\text { modern drug } \\
\text { used }\end{array}$ & $\begin{array}{c}\text { Total number } \\
\text { of dose } \\
\text { supplied* }\end{array}$ & $\begin{array}{c}\text { Total worth in } \\
\text { ETB** }\end{array}$ \\
\hline Praziquantel & 316 & $2,326.00$ \\
Niclosamide & 115 & 690.00 \\
Mebendazole & 4,942 & $12,155.00$ \\
Albendazole & 1,625 & $4,450.00$ \\
Total & 6,998 & $19,621.00$ \\
\hline
\end{tabular}

*Dose is the amount of drug used to treat one adult human taeniasis case. $* * 1 \mathrm{ETB}=0.04$ USD during the study period

epidemiology of the diseases. Conversely, this finding was higher than $2.6 \%$ at Batu, Ethiopia [34], $0.11 \%$ in 
Croatia [35], 0.2\% in South Africa [36], 0.9\% in Cuba [37], and $0.48-1.08 \%$ in Germany [38]. This could be associated with control measure and personnel hygiene application in those developed countries than in Ethiopia. Distribution of C. bovis in various organs and tissues of the infected animal was also observed with the more number of cyst in the liver than other organs inspected during the study. Elemo et al. [20] also reported cysts count of $28.6 \%-3.2 \%$ in different organs and tissue of the positive cattle in Arsi, Asella, Ethiopia. These could be due to accesses of the ingested egg via circulatory systems to specific predilection site and development into C. bovis. A number of $C$. bovis were collected from mesenteric and portal veins residing in the liver [39]. The cost associated with condemnation of the infected organs resulted in the high economic loss which was lower than the reports of Fufa [16] from other parts of Ethiopia.

About $31.8 \%$ of studied respondent are both knowledgeable on considered risk factors for infections with taeniasis (T. saginata) and have also been exposed to the disease. With the majority, $76.9 \%$ and $42.4 \%$ of respondents were aware that the source of infection is raw or undercooked meat, respectively. The present $31.8 \%$ exposure risk human taeniasis in the area is similar with $44 \%$ in Hawassa Town [40], $44.44 \%$ in Shire Indasilassie district [41], and 19\% in and around Halaba Kulito Town [29] but lower than $64 \%$ in Bishoftu [42], 62.5\% in Wolaittasoddo [43], $58 \%$ in Jimma [44], 70\% in Yirgalem [45], 56.7\% in Zeway [46], 64.2\% in Awassa town [8], 59\% in and around Batu [34], and 56.7\% in Jimma town [47], all from Ethiopia showing wide distribution and public health risk of the diseases where Desta [48] also reported the uses of herbal medication in Ethiopia. However, the present finding was lower than the 0.2$12.0 \%$ taeniasis in Vietnam [49].

One-year (2016) taeniasis case record of laboratory showed that more than 3 -fold of patients were male but female accounted low, showing concomitant prevalence with exposure risk from this study. This could be due to the fact that males consume frequently raw beef at outdoor than females in Ethiopia with higher exposer risk to $C$. bovis. Clinical symptoms ranging from nausea, abdominal pain, diarrhea, and headache to the pathognomonic sign of observing proglottids in the feces of exposed groups were observed in Ethiopia. Similar clinical symptoms and pathognomonic sign of taeniasis in infected individuals in Vietnam were reported by Van De [49]. However, unlike the present finding, Van De et al. [49] reported subcutaneous nodules, epileptic seizures, impaired vision, and memory loss in Vietnam. Pharmaceutical taenicidal drugs such as praziquantel, niclosamide, albendazole, and mebendazole [49] were supplied in studied as effective medicine. However, $28.6 \%$ of the exposed individuals use herbal medicine and $17.2 \%$ use both the pharmaceutical and herbal drugs. Desta [48] has also been studied and listed frequently used taenicidal herbal plants in
Ethiopia with its $\mathrm{LD}_{50}$ indicating a long history of the use of such treatment trend in the country.

\section{Conclusion}

The present finding indicates the prevalence of C. bovis and human taeniasis in the area with an evidence of exposure risk and clinical cases in the area. Animal organ distribution of the cyst incurred an economic loss and health risk from a public health point of view. Variable knowledge of community about the associated risk also shows the need for community education as awareness creation regarding the disease condition, associated risk factors, and application of environmental hygiene. Detailed meat inspection with proper cooking before consumption could also bring a paramount reduction of the diseases in human and beef industry which reduces the associated economic loss.

\section{Authors' Contributions}

AT: Study conduction, data collection, analysis, reference search, and manuscript writing; AH: Study conduction, data analysis, reference search, manuscript writing, and editing; KKE: Data analysis, reference search, manuscript writing, and editing. All authors have read and approved the final manuscript.

\section{Acknowledgments}

This work has no any fund available. Individuals involved on questioners are appreciated for their volunteer cooperation. Workers and manager of Kombolcha ELFORA abattoir are acknowledged for providing time while postmortem carcasses examination. The private pharmacies and the health center were thankful for the supplying all-round information.

\section{Computing Interests}

The authors declare that they have no competing interests.

\section{References}

1. Gajadhar AA, Scandrett WB, Forbes LB. Overview of foodand water-borne zoonotic parasites at the farm level. Rev Sci Tech 2006;25:595-606.

2. Taylor MA, Coop LR, Wall LR. Veterinary Parasitology. $3^{\text {rd }}$ ed. USA: Black Well Publisher; 2007. p. 121-3.

3. Onyango JA, Nginyi JM, Rugutt MK, Wright SH, Lumumba P. Seroepidemiological survey of Taenia saginata cysticercosis in Kenya. Vet Parasitol 1996;64:177-85.

4. Gebreab F. Zoonotic Diseases in Ethiopia. Ethiopian society of Animal Production. Addis Ababa: Ministry of Environment and Forestry; 1995. p. 32-6.

5. Florova AA. Epidemiology of Taeniasis. Vol. II. Moscow: Zoonoses Control Collection of Teaching Aids for International Training Course; 1982.

6. WHO. Taeniasis/cysticercosis. World Health Organization Fact Sheet No. 376; 2013.

7. Taresa G, Melaku A, Basazenuw B, Chanie M. Cyst viability, body site distribution and public health significance of Bovine cysticercosis at Jimma, south west Ethiopia. Glob Vet 2011;7:164-8.

8. Abunna F, Tilahun G, Megersa B, Regassa A, Kumsa B. Bovine cysticercosis in cattle slaughtered at Awassa municipal abattoir, Ethiopia: Prevalence, cyst viability, distribution and its public 
health implication. Zoonoses Public Health 2008;55:82-8.

9. Alum A, Rubino JR, Ijaz MK. The global war against intestinal parasites - Should we use a holistic approach? Int J Infect Dis 2010;14:e732-8

10. Teka G. Food Hygiene Principles and Food Born Disease Control with Special Reference to Ethiopia. Addis Ababa, Ethiopia: Addis Ababa University, Faculty of Medicine, Department of Community Health; 1997.

11. Tembo A. Epidemiology of Taenia saginata taeniasis and Cysticercosis in Three Selected Agro-climatic Zones in Central Ethiopia. M.Sc thesis, Faculty of Veterinary Medicine, Addis Ababa University; 2001.

12. Powloski ZS, Schultz MG. Taeniasis and of Taenia saginata. Adv Parasitol 1972;10:549-655.

13. Grindle RJ. Economic loss resulting from Bovine cysticercosis with special reference to Botswana and Kenya. Trop Anim Health Prod 2012;10:127-40.

14. Kebede N, Tilahun G, Hailu A. Current status of Bovine cysticercosis of slaughtered cattle in Addis Ababa abattoir, Ethiopia. Trop Anim Health Prod 2009;41:291-4.

15. Fan PC. Annual economic loss caused by Taenia saginata asiatica taeniasis in East Asia. Parasitol Today 1997;13:194-6.

16. Fufa A. Study on the prevalence of Bovine cysticercosis in Hawassa Municipal Abattoir and T. Saginata in Hawassa town and its surrounding South Ethiopia. MSc Thesis, FVM, AAU, Debre Zeit, Ethiopia; 2012.

17. Amsalu D. Prevalence and significance of C. bovis among slaughtered cattle at Debre Zeit abattoir. DVM Thesis, Debre Zeit, Ethiopia; 2013.

18. Issa A. Bovine Cysticercosis in Animals Slaughtered at Nekemte Abattoir. DVM Thesis, Addis Ababa University, Faculty of Veterinary Medicine, Debre Zeit, Ethiopia; 1990.

19. Tewodros AE, Annania TA, Sara TA. Study on the prevalence of Cysticercus bovis in Kombolcha Elfora, North-Eastern Ethiopia, faculty of veterinary medicine, and university of Gondar. Eur J Appl Sci 2015;7:152-7.

20. Elemo KK, Hiko A, Dawud A. Bovine cysticercosis and human teniasis with public health implication at Asella Town, Arsi Zone of Oromia regional state, Ethiopia. Bull Anim Health Prod Afr 2017;65:49-60.

21. CSA. Central Statistical Agency (CSA) Ethiopia Latest Ethiopian; 2007.

22. Thrusfield M. Sampling in Veterinary Epidemiology. Sec. Ed. London: Black Well Scince. University of Pennsylvania; 2005.

23. Arsham H. Questionnaire Design and Surveys Sampling Error! Hyperlink Reference not Valid; 2002.

24. FAO. Food and Agriculture Organization, Manual of meat Inspection for Developing Countries. FAO, Animal Production and Health; 1994. p. 119-359.

25. Gracey JF, Collins DS, Hdey RJ. Meat Hygiene. $10^{\text {th }}$ ed. London, UK: W.B. Saunders; 1999.

26. Ogunrinade A, Ogunrinade BI. Economic importance of Bovine fasciolosis in Nigeria. Trop Anim Health Prod 1980;12:155-60.

27. Lemma B, Gabre-ab F, Tedla S. Studies on fascioliasis in four selected sites in Ethiopia. Vet Parasitol 1985;18:29-37.

28. Regassa A, Abunna F, Mulugeta A, Megersa B. Major metacestodes in cattle slaughtered at Wolaita Sodo municipal abattoir, Southern Ethiopia: Prevalence, cyst viability, organ distribution and socioeconomic implications. Trop Anim Health Prod 2009;41:1495-502.

29. Abdulaziz H, Tilahun B, Moa M. Study on Bovine cysticercosis with special attention to its prevalence, economic losses and public health significance in and around Halaba Kulito Town, South Ethiopia. World J Agric Sci 2016;12:299-307.

30. Nigatu K. Cysticercus bovis: Development and evaluation of serological tests and prevalence at Addis Ababa Abattoir.
MSc Thesis, Addis Ababa University, Faculty of Veterinary Medicine, Debre Zeit, Ethiopia; 2004.

31. Endris J, Negussie H. Bovine cysticercosis: Prevalence, cyst viability and distribution in cattle slaughtered at Kombolcha Elfora meat factory, Ethiopia. Am Eur J Agric Environ Sci 2011;11:173-6

32. Kebede N. Cysticercosis of slaughtered cattle in northwestern Ethiopia. Res Vet Sci 2008;85:522-6.

33. Hailu D. Prevalence and Risk Factors for T. saginata cysticercosis in Three Selected Areas of Eastern Shoa. M.Sc Thesis, Addis Ababa University, Faculty of Veterinary Medicine, Debre Zeit, Ethiopia; 2005.

34. Teklemariam AD, Debash W. Prevalence of Taenia saginata/cysticercosis and community knowledge about zoonotic cestodes in and around Batu, Ethiopia. J Vet Sci Technol 2015;6:273

35. Zdolec N, Vujević I, Dobranić V, Juras M, Grgurević N, Ardalić D, et al. Prevalence of Cysticercus bovis in slaughtered cattle determined by traditional meat inspection in Croatian abattoir from 2005 to 2010. Helminthology 2012;49:229-32.

36. Blessing MD, Ethel KS, Mphane MM, Lebogang E, Francis RB, Rendani VN, et al. Prevalence of Bovine cysticercosis in the North West province of South Africa from 2000 to 2010. J Hum Ecol 2011;36:9-12.

37. Sau'rez HM, Santizo RM. Epidemiology of the Taenia saginata complex and C. bovis in Ciego de Avila province of Cuba. Rev Pathol Trop 2005;34:43-52.

38. Abuseir S, Epe C, Schnieder T, Klein G, Kühne M. Visual diagnosis of Taenia saginata cysticercosis during meat inspection: Is it unequivocal? Parasitol Res 2006;99:405-9.

39. Scandrett B, Parker S, Forbes L, Gajadhar A, Dekumyoy P, Waikagul J, et al. Distribution of Taenia saginata cysticerci in tissues of experimentally infected cattle. Vet Parasitol 2009;164:223-31.

40. Mesfin B, Nuradddis I. Prevalence of Cysticercus bovis in Hawassa municipal abattoir and its public health implication. Am Eur J Sci Res 2012;7:238-45.

41. Dawit G, Temesgen M. Risk factors and public health significance of cysticercosis in Cattle and Human in Shire Indasilassie District, Northern Ethiopia. Adv Biol Res 2013;7:282-7.

42. Lielt E, Desalew T, Tsegabirhan K, Teshale S, Yohannes H. Prevalence and significance of bovine cysticercosis at Elfora abattoir, Bishoftu, Ethiopia. J Public Health Epidemiol 2015;7:32-40.

43. Dawit S. Epidemiology of Taenia saginata taeniasis and Cysticercoids in North Gondar Zone, North Western Ethiopia. DVM Thesis. Faculty of Veterinary Medicine, Addis Ababa University, Debre Zeit, Ethiopia; 2004.

44. Fetene F, Nibret M. Prevalence of Bovine cysticercosis in cattle and zoonotic significance in Jimma Town, Ethiopia. Acta Parasitol Glob 2014;5:214-22.

45. Abunna F. Prevalence, organ distribution, viability and socioeconomic implication of bovine cysticercosis/taeniasis, Ethiopia. Revue D'élevageet Méd Vét Trop 2013;66:25-30.

46. Bedu H, Tafess K, Shelima B, Woldeyohannes D, Amare B, Kassu A. Bovine cysticercosis in cattle slaughtered at zeway municipal abattoir: Prevalence and its public health importance. J Vet Sci Technol 2011;2:108.

47. Megersa B, Tesfaye E, Regassa A, Abebe R, Abunna F. Bovine cysticercosis in cattle slaughtered at Jimma municipal Abattoir, South Western Ethiopia: Prevalence, cyst viability and its socio-economic importance. Vet World 2010;3:257-62.

48. Desta B. Ethiopian traditional herbal drugs. Part I: Studies on the toxicity and therapeutic activity of local taenicidal medications. J Ethnopharmacol 1995;45:27-33.

49. Van De N, Le TH, Lien PT, Eom KS. Current status of taeniasis and cysticercosis in Vietnam. Korean J Parasitol 2014;52:125-9. 